\title{
Algoriphagus yeomjeoni sp. nov., isolated from a marine solar saltern in the Yellow Sea, Korea
}

\author{
Jung-Hoon Yoon, So-Jung Kang, Seo-Youn Jung, Choong-Hwan Lee \\ and Tae-Kwang Oh
}

Correspondence

Jung-Hoon Yoon

jhyoon@kribb.re.kr

\author{
Korea Research Institute of Bioscience and Biotechnology (KRIBB), PO Box 115, Yusong, \\ Taejon, Korea
}

\begin{abstract}
Two Gram-negative, rod-shaped bacterial strains, MSS- $160^{\top}$ and MSS-161, were isolated from a marine solar saltern in the Yellow Sea, Korea, and subjected to a polyphasic taxonomic study. The two strains grew optimally in the presence of $2 \%(\mathrm{w} / \mathrm{v}) \mathrm{NaCl}$ and at $25-30^{\circ} \mathrm{C}$. Strains MSS $-160^{\top}$ and MSS-161 contained MK-7 as the predominant menaquinone and large amounts of fatty acids $\mathrm{C}_{16: 1} \omega 7 \mathrm{c}$ and/or iso- $\mathrm{C}_{15: 0} 2-\mathrm{OH}$ and iso- $\mathrm{C}_{15: 0}$. The DNA $\mathrm{G}+\mathrm{C}$ content of the two strains was 41 mol\%. Phylogenetic analyses based on 16S rRNA gene sequences showed that the two strains were phylogenetically affiliated to the genus Algoriphagus. Strains MSS $-160^{\top}$ and MSS-161 exhibited no difference in their 16S rRNA gene sequences and possessed a mean DNA-DNA relatedness level of $91 \%$; they exhibited $16 \mathrm{~S}$ rRNA similarity levels of $96 \cdot 6-99 \cdot 3 \%$ to the type strains of Algoriphagus species with validly published names. DNA-DNA relatedness levels between the two strains and the type strains of five Algoriphagus species were lower than $46 \%$. On the basis of phenotypic, phylogenetic and genetic data, strains MSS-160 ${ }^{\top}$ and MSS-161 were classified in the genus Algoriphagus as members of a novel species, for which the name Algoriphagus yeomjeoni sp. nov. (type strain, MSS $-160^{\top}=\mathrm{KCTC} 12309^{\top}=\mathrm{JCM} 12598^{\top}$ ) is proposed.
\end{abstract}

The genus Algoriphagus was proposed by Bowman et al. (2003) with the single species Algoriphagus ratkowskyi. Subsequently, four further Algoriphagus species, Algoriphagus aquimarinus, Algoriphagus chordae and Algoriphagus winogradskyi (Nedashkovskaya et al., 2004) and Algoriphagus antarcticus (Van Trappen et al., 2004) have been described. Hongiella halophila was transferred to the genus Algoriphagus as Algoriphagus halophilus by Nedashkovskaya et al. (2004). The genus Algoriphagus accommodates strictly aerobic, Gram-negative, non-motile, pink-pigmented, oxidase-positive and rod-shaped bacteria (Bowman et al., 2003; Nedashkovskaya et al., 2004; Van Trappen et al., 2004). Phylogenetic analyses based on $16 \mathrm{~S}$ rRNA gene sequences showed that the genus is phylogenetically related to the Cytophaga-Flavobacterium-Bacteroides group (Bowman et al., 2003; Nedashkovskaya et al., 2004; Van Trappen et al., 2004). The genus Algoriphagus is characterized chemotaxonomically by having $\mathrm{MK}-7$ as the predominant menaquinone and by a DNA $\mathrm{G}+\mathrm{C}$ content of 35-42 mol\% (Bowman et al., 2003; Nedashkovskaya et al., 2004; Van Trappen et al., 2004). In the study presented here,

Published online ahead of print on 5 November 2004 as DOI 10.1099/ ijs.0.63479-0.

The GenBank/EMBL/DDBJ accession numbers for the 16S rRNA gene sequences of strains MSS-160 ${ }^{\top}$ and MSS-161 are AY699794 and AY699795, respectively. we report on the taxonomic characterization of two slightly halophilic vivid orange-pigmented Algoriphagus-like bacterial strains, MSS- $160^{\mathrm{T}}$ and MSS-161, which were isolated from a marine solar saltern in the Yellow Sea, Korea.

Strains MSS $-160^{\mathrm{T}}$ and MSS-161 were isolated by the standard dilution plating technique at $25^{\circ} \mathrm{C}$ on marine agar 2216 (MA; Difco). A. ratkowskyi CIP $107452^{\mathrm{T}}$ was obtained from the Collection de l'Institut Pasteur (CIP), Paris, France. A. aquimarinus LMG $21971^{\mathrm{T}}$, A. chordae LMG $21970^{\mathrm{T}}$, A. winogradskyi LMG $21969^{\mathrm{T}}$ and A. antarcticus LMG $21980^{\mathrm{T}}$ were obtained from the Laboratorium voor Microbiologie Universiteit Gent (LMG), Gent, Belgium. To investigate their morphological and physiological characteristics, strains MSS- $160^{\mathrm{T}}$ and MSS-161 were routinely cultivated at $30{ }^{\circ} \mathrm{C}$ on MA. Cell morphology was examined by light microscopy (Nikon E600) and transmission electron microscopy (TEM). Presence of flagella was examined by TEM using cells from exponentially growing cultures. Gliding motility was determined as described by Bowman (2000). Gram reaction was determined using the bioMérieux Gram Stain kit according to the manufacturer's instructions. Growth at various temperatures $\left(4-40{ }^{\circ} \mathrm{C}\right)$ was measured on $\mathrm{MA}$. The $\mathrm{pH}$ range for growth was determined in marine broth 2216 (MB; Difco) that was adjusted to various $\mathrm{pH}$ values $(\mathrm{pH} 4 \cdot 5-9 \cdot 5$ at intervals of $0.5 \mathrm{pH}$ units). Growth under anaerobic conditions was 
determined after incubation in a Forma anaerobic chamber on MA and MA supplemented with nitrate, both of which had been prepared anaerobically using nitrogen. Catalase and oxidase activities and hydrolysis of casein, starch and Tweens 20, 40, 60 and 80 were determined as described by Cowan \& Steel (1965). Hydrolysis of hypoxanthine, tyrosine and xanthine was tested on MA using the substrate concentrations described by Cowan \& Steel (1965). Hydrolysis of aesculin, gelatin and urea and nitrate reduction were studied as described previously (Lanyi, 1987) with the modification that artificial sea water was used for preparation of media. The artificial sea water contained (per litre of distilled water) $23.6 \mathrm{~g} \mathrm{NaCl}, 0.64 \mathrm{~g} \mathrm{KCl}, 4.53 \mathrm{~g}$ $\mathrm{MgCl}_{2} \cdot 6 \mathrm{H}_{2} \mathrm{O}, 5.94 \mathrm{~g} \mathrm{MgSO}_{4} \cdot 7 \mathrm{H}_{2} \mathrm{O}$ and $1.3 \mathrm{~g} \mathrm{CaCl}_{2} \cdot 2 \mathrm{H}_{2} \mathrm{O}$ (Bruns et al., 2001). $\mathrm{H}_{2} \mathrm{~S}$ production was tested as described by Bruns et al. (2001). Presence of flexirubin pigment was investigated as described by Reichenbach (1992). Susceptibility to antibiotics was detected on MA plates by using antibiotic discs with the following concentrations: ampicillin $(10 \mu \mathrm{g})$, benzylpenicillin $(10 \mu \mathrm{g})$, carbenicillin $(100 \mu \mathrm{g})$, gentamicin $(10 \mu \mathrm{g})$, kanamycin $(30 \mu \mathrm{g})$, lincomycin $(15 \mu \mathrm{g})$, neomycin $(30 \mu \mathrm{g})$, oleandomycin $(15 \mu \mathrm{g})$, polymyxin B $(300 \mathrm{U})$, streptomycin $(10 \mu \mathrm{g})$, chloramphenicol $(100 \mu \mathrm{g})$ and tetracycline $(30 \mu \mathrm{g})$. Acid production from carbohydrates was determined as described by Leifson (1963). Utilization of various substrates for growth was determined as described by Yurkov et al. (1994).

Cell biomass for isoprenoid quinone analysis and for DNA extraction was obtained from cultivation for 3 days in $\mathrm{MB}$ at $30^{\circ} \mathrm{C}$. Isoprenoid quinones were analysed as described by Komagata \& Suzuki (1987) using reversed-phase HPLC. Chromosomal DNA was isolated and purified according to the method described previously (Yoon et al., 1996), with the exception that ribonuclease T1 was applied in combination with ribonuclease A to minimize the contamination of RNA. For fatty acid methyl ester (FAME) analysis, cell mass of the two strains was harvested from agar plates after incubation for 5 days on MA at $30^{\circ} \mathrm{C}$. The FAMEs were extracted and prepared according to the standard protocol of the MIDI/Hewlett Packard Microbial Identification System (Sasser, 1990). The DNA G+C content was determined by the method of Tamaoka \& Komagata (1984) with the modification that DNA was hydrolysed and the resultant nucleotides were analysed by reversed-phase HPLC.

The 16S rRNA gene was amplified by PCR using two universal primers as described previously (Yoon et al., 1998). Sequencing of the amplified 16S rRNA gene was performed as described by Yoon et al. (2003). Alignment of sequences was carried out with CLUSTAL W software (Thompson et al., 1994). Gaps at the $5^{\prime}$ and $3^{\prime}$ ends of the alignment were omitted from further analyses. Phylogenetic trees were inferred by using three tree-making algorithms, the neighbour-joining (Saitou \& Nei, 1987), maximumlikelihood (Felsenstein, 1981) and maximum-parsimony (Kluge \& Farris, 1969) methods implemented within the
PHYLIP package (Felsenstein, 1993). Evolutionary distance matrices for the neighbour-joining method were calculated by the algorithm of Jukes \& Cantor (1969) using the program DNADIST. The stability of relationships was assessed by a bootstrap analysis based on 1000 resamplings of the neighbour-joining dataset by using the programs SEQBOOT, DNADIST, NEIGHBOR and CONSENSE of the PHYLIP package. DNA-DNA hybridization was performed fluorometrically by the method of Ezaki et al. (1989) using photobiotinlabelled DNA probes and microdilution wells. Hybridization was performed with five replications for each sample. The highest and lowest values obtained in each sample were excluded, and the remaining three values were used to calculate similarity values. The DNA relatedness values quoted are the mean of the three values.

Strains MSS $-160^{\mathrm{T}}$ and MSS- 161 grew optimally at $25-30{ }^{\circ} \mathrm{C}$ and $\mathrm{pH} 7 \cdot 0-8 \cdot 0$ and in the presence of $2 \%(\mathrm{w} / \mathrm{v}) \mathrm{NaCl}$. The two strains were similar in most phenotypic characteristics except the following characteristics; gelatin hydrolysis and acid production from D-mannose and D-raffinose. Morphological, cultural, physiological and biochemical characteristics of the two strains are shown in Table 1 or given in the species description (see below).

Strains MSS $-160^{\mathrm{T}}$ and MSS-161 contained menaquinone-7 (MK-7) as the predominant isoprenoid quinone at peak area ratio of approximately $94-96 \%$. The two strains had cellular fatty acid profiles that contained large amounts of branched, unsaturated and hydroxy fatty acids; the major fatty acids were $\mathrm{C}_{16: 1} \omega 07 c$ and/or iso- $\mathrm{C}_{15: 0} 2-\mathrm{OH}$ and iso$\mathrm{C}_{15: 0}$ (Table 2). The DNA G+C contents of strains MSS$160^{\mathrm{T}}$ and MSS-161 were the same, $41 \mathrm{~mol} \%$. The $16 \mathrm{~S}$ rRNA gene sequences of strains MSS- $160^{\mathrm{T}}$ and MSS-161 determined in this study comprised 1476 nucleotides, respectively, representing approximately $96 \%$ of the Escherichia coli 16S rRNA gene sequence. The 16S rRNA gene sequences of strains MSS- $160^{\mathrm{T}}$ and MSS-161 were identical. The phylogenetic analyses based on 16S rRNA gene sequences showed that strains MSS $-160^{\mathrm{T}}$ and MSS- 161 fall within the radiation of the cluster comprising Algoriphagus species (Fig. 1). The two strains exhibited highest 16S rRNA similarity value $(99 \cdot 3 \%)$ to the type strain of A. winogradskyi, and $16 \mathrm{~S}$ rRNA similarity levels of $96 \cdot 6-98 \cdot 5 \%$ to the type strains of the other Algoriphagus species. The two strains exhibited 16S rRNA similarity levels of less than $95.0 \%$ to other species included in the phylogenetic analysis. DNA-DNA hybridization was performed to determine the genetic relatedness between strains MSS- $160^{\mathrm{T}}$ and MSS161 and between the two strains and the type strains of Algoriphagus species. Strains MSS- $160^{\mathrm{T}}$ and MSS-161 exhibited a mean level of DNA-DNA relatedness of $91 \%$, when their DNAs were used individually as labelled DNA probes for cross-hybridization. This value indicates that the two strains are members of the same genomic species. DNA-DNA relatedness levels between the two strains and the type strains of six Algoriphagus species were in the range $12-46 \%$. 
Table 1. Differential phenotypic characteristics of Algoriphagus species

Species: 1, A. ratkowskyi; 2, A. aquimarinus; 3, A. chordae; 4, A. winogradskyi; 5, A. halophilus; 6, A. antarcticus; 7, A. yeomjeoni sp. nov. +, Positive; -, negative; W, weakly positive; V, variable reaction; ND, not determined. All species are: Gram-negative and rod-shaped; positive for catalase and oxidase; negative for gliding motility, flexirubin pigment production, $\mathrm{H}_{2} \mathrm{~S}$ and indole production, utilization of citrate, susceptibility to ampicillin, benzylpenicillin, gentamicin, kanamycin, neomycin, polymyxin B and streptomycin.

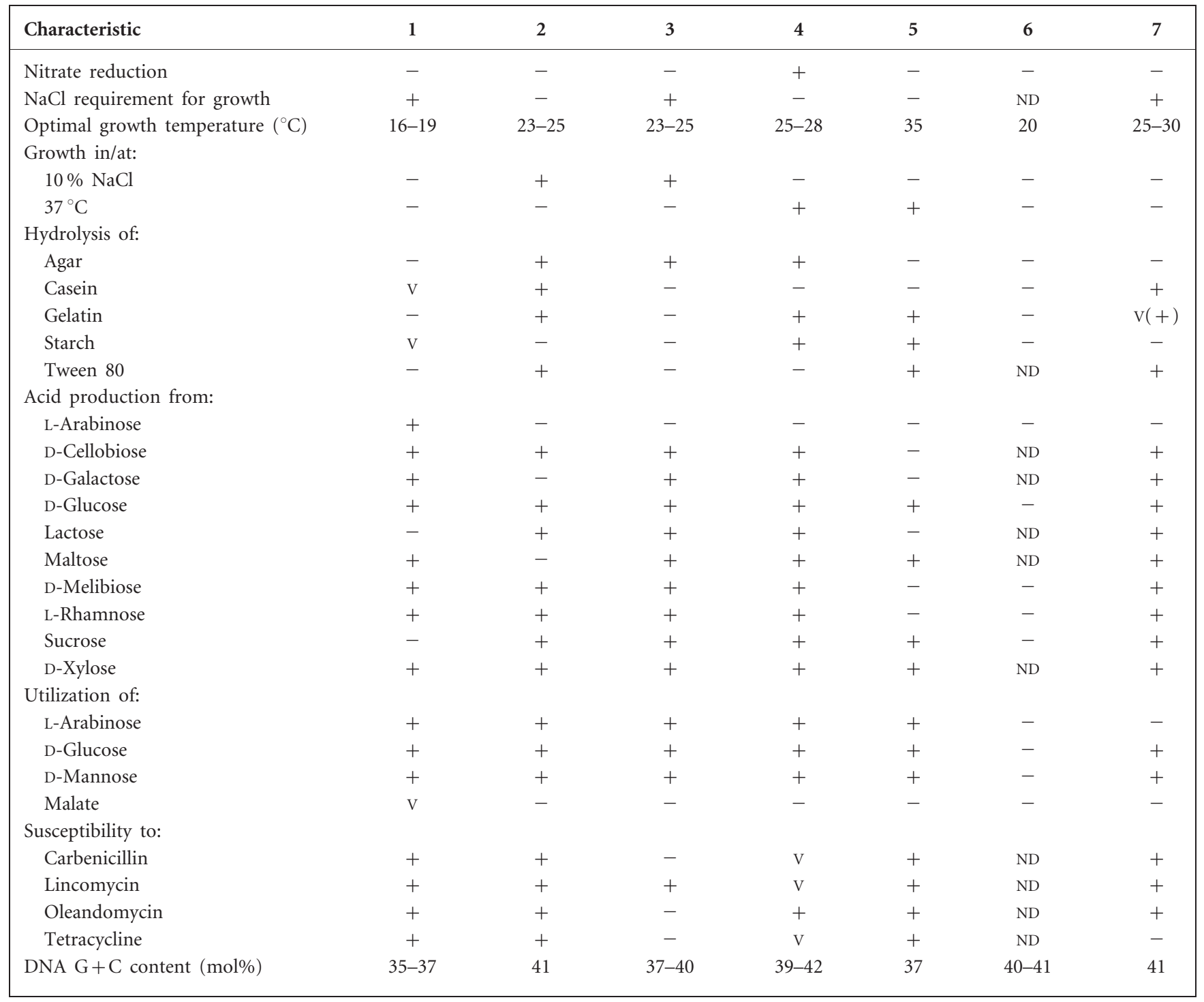

The result of $16 \mathrm{~S}$ rRNA gene sequence analysis revealed that strains MSS- $160^{\mathrm{T}}$ and MSS-161 have closest phylogenetic affiliations to the genus Algoriphagus (Fig. 1). The results obtained from chemotaxonomic analyses are consistent with the results of 16S rRNA gene sequence analysis and phylogenetic inference. The predominant menaquinone of the two strains was the same as that in other Algoriphagus species (Nedashkovskaya et al., 2004). The fatty acid profiles of the two strains were similar to those of the type strains of Algoriphagus species analysed previously, although there were differences in the compositions of some fatty acids between the two strains and the type strains of Algoriphagus species (Table 2). The DNA G $+\mathrm{C}$ contents of the strains were in the range for Algoriphagus species (Bowman et al.,
2003; Nedashkovskaya et al., 2004; Van Trappen et al., 2004). The phenotypic, phylogenetic and genetic similarities warrant that strains MSS- $160^{\mathrm{T}}$ and MSS-161 are members of the same species. The genetic distinctiveness, together with $16 \mathrm{~S}$ rRNA similarity data, was enough to categorize the two strains as a species distinct from previously described Algoriphagus species (Wayne et al., 1987; Stackebrandt \& Goebel, 1994). Strains MSS- $160^{\mathrm{T}}$ and MSS-161 were also distinguishable from the six Algoriphagus species by some differences in phenotypic properties (Table 1). Therefore, on the basis of the data presented, strains MSS $-160^{\mathrm{T}}$ and MSS-161 should be placed in the genus Algoriphagus as members of a novel species, for which the name Algoriphagus yeomjeoni sp. nov. is proposed. 
Table 2. Cellular fatty acid compositions (\%) of Algoriphagus species

Strains: 1, A. ratkowskyi LMG $21435^{\mathrm{T}}$; 2, A. aquimarinus KMM $3958^{\mathrm{T}}$; 3, A. chordae KMM 3957 ${ }^{\mathrm{T}}$; 4, A. winogradskyi KMM $3956^{\mathrm{T}}$; 5 , A. halophilus LMG $22067^{\mathrm{T}}$; 6, A. yeomjeoni MSS-160 ; 7, A. yeomjeoni MSS-161. Data for reference strains were taken from Nedashkovskaya et al. (2004). Fatty acids that represented less than $0.5 \%$ in all strains were omitted. ND, Not detected.

\begin{tabular}{|c|c|c|c|c|c|c|c|}
\hline Fatty acid & 1 & 2 & 3 & 4 & 5 & 6 & 7 \\
\hline \multicolumn{8}{|l|}{ Straight-chain } \\
\hline $\mathrm{C}_{15: 0}$ & $1 \cdot 6$ & $1 \cdot 6$ & $2 \cdot 5$ & $1 \cdot 2$ & $1 \cdot 0$ & $0 \cdot 6$ & $0 \cdot 8$ \\
\hline $\mathrm{C}_{16: 0}$ & $2 \cdot 9$ & $1 \cdot 7$ & $1 \cdot 4$ & $1 \cdot 0$ & - & $0 \cdot 8$ & 0.9 \\
\hline \multicolumn{8}{|l|}{ Branched } \\
\hline anteiso- $\mathrm{C}_{11: 0}$ & $2 \cdot 1$ & $0 \cdot 6$ & $1 \cdot 0$ & $1 \cdot 2$ & $1 \cdot 5$ & - & - \\
\hline iso- $\mathrm{C}_{14: 0}$ & $1 \cdot 4$ & $0 \cdot 7$ & $0 \cdot 3$ & $0 \cdot 3$ & $0 \cdot 6$ & $1 \cdot 6$ & $1 \cdot 3$ \\
\hline iso- $\mathrm{C}_{15: 0}$ & $30 \cdot 5$ & $38 \cdot 9$ & $38 \cdot 1$ & $36 \cdot 6$ & $28 \cdot 4$ & $28 \cdot 6$ & $30 \cdot 1$ \\
\hline iso- $\mathrm{C}_{15: 1} \mathrm{G}$ & $1 \cdot 1$ & $0 \cdot 3$ & - & $2 \cdot 9$ & - & - & $0 \cdot 6$ \\
\hline anteiso- $\mathrm{C}_{15: 0}$ & $3 \cdot 6$ & $3 \cdot 2$ & $1 \cdot 9$ & $1 \cdot 6$ & $2 \cdot 8$ & $1 \cdot 2$ & $1 \cdot 2$ \\
\hline iso- $\mathrm{C}_{16: 0}$ & $3 \cdot 4$ & $2 \cdot 4$ & $5 \cdot 8$ & $3 \cdot 9$ & $7 \cdot 7$ & $4 \cdot 8$ & $4 \cdot 9$ \\
\hline iso- $\mathrm{C}_{16: 1} \mathrm{H}$ & $1 \cdot 7$ & $2 \cdot 4$ & $1 \cdot 5$ & $2 \cdot 1$ & $3 \cdot 5$ & $1 \cdot 9$ & $1 \cdot 7$ \\
\hline iso- $\mathrm{C}_{17: 1} \omega 9 c$ & $1 \cdot 5$ & $5 \cdot 3$ & $4 \cdot 4$ & $4 \cdot 0$ & $9 \cdot 0$ & $2 \cdot 3$ & $2 \cdot 1$ \\
\hline \multicolumn{8}{|l|}{ Unsaturated } \\
\hline $\mathrm{C}_{15: 1} \omega 6 c$ & $2 \cdot 1$ & $2 \cdot 3$ & $1 \cdot 0$ & $1 \cdot 3$ & $1 \cdot 8$ & $0 \cdot 8$ & $1 \cdot 0$ \\
\hline $\mathrm{C}_{16: 1} \omega 5 c$ & $5 \cdot 8$ & $5 \cdot 2$ & $3 \cdot 6$ & $3 \cdot 6$ & $3 \cdot 5$ & $3 \cdot 3$ & $3 \cdot 2$ \\
\hline $\mathrm{C}_{17: 1} \omega 6 c$ & $0 \cdot 5$ & $0 \cdot 7$ & $1 \cdot 2$ & $0 \cdot 8$ & $3 \cdot 4$ & $1 \cdot 0$ & $0 \cdot 8$ \\
\hline \multicolumn{8}{|l|}{ Hydroxy } \\
\hline iso- $\mathrm{C}_{15: 0} 3-\mathrm{OH}$ & $2 \cdot 9$ & $1 \cdot 8$ & $1 \cdot 6$ & $2 \cdot 0$ & $2 \cdot 5$ & $3 \cdot 0$ & $3 \cdot 1$ \\
\hline $\mathrm{C}_{16: 0} 2-\mathrm{OH}$ & - & - & - & - & - & $1 \cdot 3$ & $1 \cdot 0$ \\
\hline $\mathrm{C}_{16: 0} 3-\mathrm{OH}$ & $1 \cdot 9$ & $0 \cdot 5$ & $1 \cdot 9$ & $0 \cdot 8$ & $0 \cdot 7$ & $1 \cdot 1$ & $1 \cdot 2$ \\
\hline iso- $\mathrm{C}_{16: 0} 3-\mathrm{OH}$ & $2 \cdot 8$ & $1 \cdot 0$ & $0 \cdot 9$ & $1 \cdot 9$ & $3 \cdot 1$ & $3 \cdot 3$ & $3 \cdot 5$ \\
\hline iso- $\mathrm{C}_{17: 0} 3-\mathrm{OH}$ & $9 \cdot 2$ & $5 \cdot 9$ & $6 \cdot 4$ & $6 \cdot 4$ & $5 \cdot 9$ & $7 \cdot 8$ & $7 \cdot 3$ \\
\hline \multicolumn{8}{|c|}{ Summed feature ${ }^{*}$} \\
\hline 3 & $22 \cdot 3$ & $20 \cdot 4$ & $22 \cdot 2$ & $24 \cdot 6$ & $19 \cdot 0$ & $33 \cdot 7$ & $29 \cdot 1$ \\
\hline 4 & $0 \cdot 9$ & $1 \cdot 8$ & $1 \cdot 7$ & $1 \cdot 6$ & $2 \cdot 7$ & $1 \cdot 3$ & $1 \cdot 1$ \\
\hline
\end{tabular}

${ }^{*}$ Summed feature represents groups of two or three fatty acids that could not be separated by GLC with the MIDI system. Summed feature 3 contained one or more of $\mathrm{C}_{16: 1} \omega 7 c$ and/or iso- $\mathrm{C}_{15: 0}$ 2-OH. Summed feature 4 contained one or more of iso- $\mathrm{C}_{17: 1} \mathrm{I}$ and/or anteiso- $\mathrm{C}_{17: 1} \mathrm{~B}$.

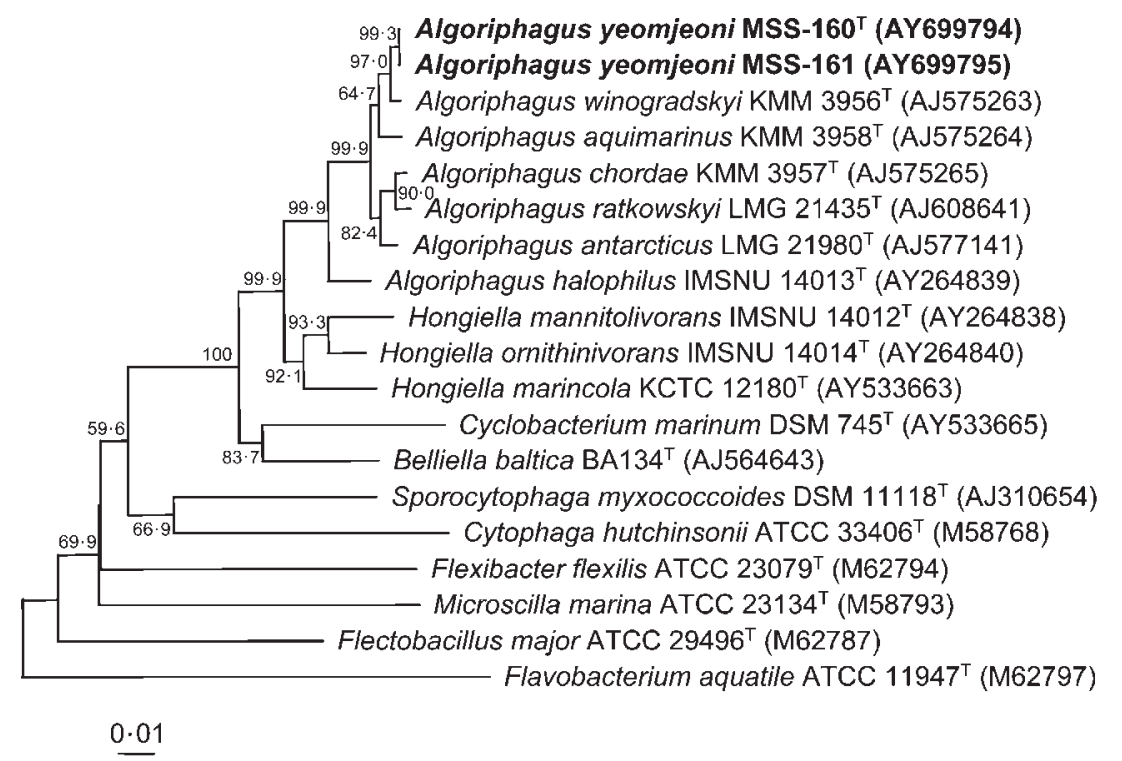

Fig. 1. Neighbour-joining phylogenetic tree based on 16S rRNA gene sequences showing the positions of strains MSS $-160^{\top}$ and MSS-161 and some other related taxa. The numbers on the branches indicate the bootstrap value of 1000 resamplings (greater than $50 \%$ ). Bar, 0.01 substitution per nucleotide position. 


\section{Description of Algoriphagus yeomjeoni sp. nov.}

Algoriphagus yeomjeoni (yeom.jeo' ni. N.L. gen. n. yeomjeoni of yeomjeon, the Korean name for a marine solar saltern).

Cells are Gram-negative and non-flagellated rods, $0 \cdot 4-$ $0.7 \times 1 \cdot 5-2.5 \mu \mathrm{m}$. Non-motile. Colonies are circular, convex, vivid orange in colour and $0.8-1.0 \mathrm{~mm}$ after 3 days incubation on $\mathrm{MA}$ at $30^{\circ} \mathrm{C}$. Growth occurs at 4 and $35^{\circ} \mathrm{C}$, with an optimum temperature of $25-30^{\circ} \mathrm{C}$; growth does not occur above $36^{\circ} \mathrm{C}$. Optimal $\mathrm{pH}$ for growth is between $7 \cdot 0$ and $8 \cdot 0$; growth is observed at $\mathrm{pH} 5 \cdot 0$, but not at $\mathrm{pH} 4 \cdot 5$. Optimal growth occurs in the presence of $2 \%(\mathrm{w} / \mathrm{v}) \mathrm{NaCl}$; growth does not occur in the presence of greater than $9 \%(\mathrm{w} / \mathrm{v}) \mathrm{NaCl}$. Growth does not occur under anaerobic conditions on MA and MA supplemented with nitrate. Flexirubin pigment is absent. Aesculin and Tweens 20, 40 and 60 are hydrolysed. Hypoxanthine, xanthine, tyrosine and urea are not hydrolysed. Susceptible to chloramphenicol. D-Cellobiose, D-fructose, D-galactose, maltose, sucrose, D-trehalose and salicin are utilized as carbon and energy sources, but D-xylose, acetate, benzoate, formate, pyruvate, succinate and L-glutamate are not. Acid is produced from D-fructose and D-trehalose. No acid is produced from D-melezitose, D-ribose, myo-inositol, Dmannitol or D-sorbitol. Acid production from D-mannose (negative for type strain) and D-raffinose (positive for type strain) is variable. Predominant menaquinone is MK-7. Major fatty acids are $\mathrm{C}_{16: 1} \omega 7 c$ and/or iso- $\mathrm{C}_{15: 0} 2-\mathrm{OH}$ and iso- $\mathrm{C}_{15: 0}$. DNA $\mathrm{G}+\mathrm{C}$ content is $41 \mathrm{~mol} \%$. Other phenotypic properties are given in Table 1.

The type strain, MSS $-160^{\mathrm{T}}\left(=\mathrm{KCTC} 12309^{\mathrm{T}}=\mathrm{JCM} 12598^{\mathrm{T}}\right)$, was isolated from a marine solar saltern in the Yellow Sea, Korea. Reference strain is MSS-161.

\section{Acknowledgements}

This work was supported by the 21C Frontier program of Microbial Genomics and Applications (grant MG02-0401-001-1-0-0) from the Ministry of Science and Technology (MOST) of the Republic of Korea.

\section{References}

Bowman, J. P. (2000). Description of Cellulophaga algicola sp. nov., isolated from the surfaces of Antarctic algae, and reclassification of Cytophaga uliginosa (ZoBell and Upham 1944) Reichenbach 1989 as Cellulophaga uliginosa comb. nov. Int J Syst Evol Microbiol 50, 1861-1868.

Bowman, J. P., Nichols, C. M. \& Gibson, J. A. E. (2003). Algoriphagus ratkowskyi gen. nov., sp. nov., Brumimicrobium glaciale gen. nov., sp. nov., Cryomorpha ignava gen. nov., sp. nov. and Crocinitomix catalasitica gen. nov., sp. nov., novel flavobacteria isolated from various polar habitats. Int J Syst Evol Microbiol 53, 1343-1355.

Bruns, A., Rohde, M. \& Berthe-Corti, L. (2001). Muricauda ruestringensis gen. nov., sp. nov., a facultatively anaerobic, appendaged bacterium from German North Sea intertidal sediment. Int J Syst Evol Microbiol 51, 1997-2006.

Cowan, S. T. \& Steel, K. J. (1965). Manual for the Identification of Medical Bacteria. London: Cambridge University Press.
Ezaki, T., Hashimoto, Y. \& Yabuuchi, E. (1989). Fluorometric deoxyribonucleic acid-deoxyribonucleic acid hybridization in microdilution wells as an alternative to membrane filter hybridization in which radioisotopes are used to determine genetic relatedness among bacterial strains. Int J Syst Bacteriol 39, 224-229.

Felsenstein, J. (1981). Evolutionary trees from DNA sequences: a maximum likelihood approach. J Mol Evol 17, 368-376.

Felsenstein, J. (1993). PHYLIP (phylogeny inference package), version 3.5. Department of Genetics, University of Washington, Seattle, USA.

Jukes, T. H. \& Cantor, C. R. (1969). Evolution of protein molecules. In Mammalian Protein Metabolism, vol. 3, pp. 21-132. Edited by H. N. Munro. New York: Academic Press.

Kluge, A. G. \& Farris, F. S. (1969). Quantitative phyletics and the evolution of anurans. Syst Zool 18, 1-32.

Komagata, K. \& Suzuki, K. (1987). Lipid and cell wall analysis in bacterial systematics. Methods Microbiol 19, 161-207.

Lanyi, B. (1987). Classical and rapid identification methods for medically important bacteria. Methods Microbiol 19, 1-67.

Leifson, E. (1963). Determination of carbohydrate metabolism of marine bacteria. J Bacteriol 85, 1183-1184.

Nedashkovskaya, O. I., Vancanneyt, M., Van Trappen, S. \& 7 other authors (2004). Description of Algoriphagus aquimarinus sp. nov., Algoriphagus chordae sp. nov. and Algoriphagus winogradskyi sp. nov., from sea water and algae, transfer of Hongiella halophila Yi and Chun 2004 to the genus Algoriphagus as Algoriphagus halophilus comb. nov. and emended descriptions of the genera Algoriphagus Bowman et al. 2003 and Hongiella Yi and Chun 2004. Int J Syst Evol Microbiol 54, 1757-1764.

Reichenbach, H. (1992). The order Cytophagales. In The Prokaryotes, a Handbook on the Biology of Bacteria: Ecophysiology, Isolation, Identification, Applications, 2nd edn, pp. 3631-3675. Edited by A. Balows, H. G. Trüper, M. Dworkin, W. Harder \& K. H. Schleifer. New York: Springer.

Saitou, N. \& Nei, M. (1987). The neighbor-joining method: a new method for reconstructing phylogenetic trees. Mol Biol Evol 4, 406-425.

Sasser, M. (1990). Identification of Bacteria by Gas Chromatography of Cellular Fatty Acids. Newark, DE: MIDI.

Stackebrandt, E. \& Goebel, B. M. (1994). Taxonomic note: a place for DNA-DNA reassociation and 16S rRNA sequence analysis in the present species definition in bacteriology. Int J Syst Bacteriol 44, 846-849.

Tamaoka, J. \& Komagata, K. (1984). Determination of DNA base composition by reverse-phase high-performance liquid chromatography. FEMS Microbiol Lett 25, 125-128.

Thompson, J. D., Higgins, D. G. \& Gibson, T. J. (1994). CLUSTAL W: improving the sensitivity of progressive multiple sequence alignment through sequence weighting, position-specific gap penalties and weight matrix choice. Nucleic Acids Res 22, 4673-4680.

Van Trappen, S., Vandecandelaere, I., Mergaert, J. \& Swings, J. (2004). Algoriphagus antarcticus sp. nov., a novel psychrophile from microbial mats in Antarctic lakes. Int J Syst Evol Microbiol 54, 1969-1973.

Wayne, L. G., Brenner, D. J., Colwell, R. R. \& 9 other authors (1987). International Committee on Systematic Bacteriology. Report of the ad hoc committee on reconciliation of approaches to bacterial systematics. Int J Syst Bacteriol 37, 463-464.

Yoon, J.-H., Km, H., Kim, S.-B., Kim, H.-J., Kim, W. Y., Lee, S. T., Goodfellow, M. \& Park, Y.-H. (1996). Identification of Saccharomonospora strains by the use of genomic DNA fragments and rRNA gene probes. Int J Syst Bacteriol 46, 502-505. 
Yoon, J.-H., Lee, S. T. \& Park, Y.-H. (1998). Inter- and intraspecific phylogenetic analysis of the genus Nocardioides and related taxa based on 16S rDNA sequences. Int J Syst Bacteriol 48, 187-194.

Yoon, J.-H., Kim, I.-G., Shin, D.-Y., Kang, K. H. \& Park, Y.-H. (2003). Microbulbifer salipaludis sp. nov., a moderate halophile isolated from a Korean salt marsh. Int J Syst Evol Microbiol 53, 53-57.
Yurkov, V., Stackebrandt, E., Holmes, A. \& 7 other authors (1994). Phylogenetic positions of novel aerobic, bacteriochlorophyll a-containing bacteria and description of Roseococcus thiosulfatophilus gen. nov., sp. nov., Erythromicrobium ramosum gen. nov., sp. nov., and Erythrobacter litoralis sp. nov. Int J Syst Bacteriol 44, $427-434$. 